UDC: $371.13+004$

DOI: https://doi.org/10.24195/2414-4665-2017-5-5

Igor Racu,

Doctor of Psychology, professor, Department of Psychology, vice-rector for research and international relations, Ion Creangă Pedagogical State University, 1, I. Creangă Str., Chisinau, Republic of Moldova,

Oleksii Lystopad,

Doctor of Pedagogy, associate professor,

Iryna Mardarova,

PhD (Candidate of Pedagogical Sciences), senior lecturer, Department of Preschool Pedagogy, South Ukrainian National Pedagogical University named after K. D. Ushynsky, 26, Staroportofrankivska Str., Odessa, Ukraine

\title{
THE FORMATION OF FUTURE PRESCHOOL TEACHERS' COMPETENCE REQUIRED FOR USING COMPUTER TECHNOLOGY
}

The paper aims to analyse the peculiarities of the formation of future preschool teachers' competence required for applying computer technology when learning the disciplines "New Information Technology in Preschool Education" and “Computer Technology in Work with Children”. The formation of students' competence required for using computer technology in the educational process of a preschool educational institution is an integrated process, which involves psychopedagogical, methodological, technical training and the testing of the acquired knowledge and abilities in the process of practical training at a preschool educational institution. The level of the above-mentioned competence formation was assessed before and after studying the courses "New Information Technology in Preschool Education" and "Computer Technology in Work with Children" by future preschool teachers. The results of the study have shown that the level of future preschool teachers' competence formation has increased significantly after studying these disciplines. tions.

Keywords: competence, future preschool teachers, computer technology, educational process of preschool institu-

\section{Introduction}

Present-day world is characterised by the implementation of computer technology in the work of educational institutions. The idea of using computer equipment has led to qualitative changes of methods, forms and content of teaching. The society's informatisation creates new educational standards, which require the implementation of contemporary computer technology starting from preschool education. It is supported by the following documents: the Law of Ukraine "On Education", Basic Component of Preschool Education (2012), The Programme for Preschool Children's Development "Me in the world", etc. The criteria for informative competency of a pre-schooler according to the national standard are as follows: computer skills including management of the machine by means of a keyboard, a mouse; the ability to understand and use specific terminology and elementary techniques of using a computer for games, training and brain games developed for preschool children; the ability to adhere to safety instructions while working a computer [1, p. 18].

Reformation of the system of preschool education requires intensive use of contemporary means, methods and forms that facilitate the enhancement of the effectiveness of the educational process of a preschool institution. Some researchers believe that computer technology provides massive opportunities in solving this problem $(\mathrm{N}$.
Volkova, Yu. Horvitsa, N. Lysenko, N. Kirsti, S. Novosolova, Yu. Oliinyk). Computer technology enables children to learn in an interesting way, find new sources of information, develop independence and reasonability [3, p. 404].

The latter stipulates the necessity to review the priorities in the system of training future preschool teachers, where the formation of their competence in terms of reasonable and effective use of computer technology in the educational process of preschool institutions takes on particular significance together with the formation of professional knowledge, abilities and skills. For this purpose, it is necessary to radically change the forms and methods of teaching, to represent the information in such a manner that can arouse student's creativity and desire to use computer technology in their future work. Some aspects of preparing future preschool teachers for applying computer technology in the educational process of a preschool institution were studied by L. Habdulislamova, N. Dykanska, S. Diachenko et al.

The paper aims to analyse the peculiarities of the formation of future preschool teachers' competence required for applying computer technology when learning the disciplines "New Information Technology in Preschool Education" and "Computer Technology in Work with Children". 


\section{Discussion}

Under conditions of wide use of computer technology (CT) in the educational process of a preschool institution, the requirements to preschool teachers' professional training are becoming stricter. They are expected to improve their professional competence on a regular basis, be able to adjust themselves to the conditions of efficient use of the most advanced computer equipment. The crucial role in training preschool teachers is played by higher pedagogical educational institutions, as long as they set the methodological, content-related and technological parameters of education at all levels, form their pedagogical thinking, excellence and professional competence.

It is known that the implementation of CT into the educational process by preschool teachers enables them to present new material to children simply and effectively, developing their creative capabilities, cognitive motivation, skills of social communication, independence, good organisation, concentration, single-mindedness, persistence, determination, etc.

Therefore, future preschool teachers' competence required for using $\mathrm{CT}$ in the educational process of a preschool institution is considered as their understanding of the aim, forms and methods of its use; interest and need to use it in future work; professional abilities and skills that provide implementation of this technology in the work with children and parents; sharing experience, selfeducation, etc. This competence is a component of general university training of preschool teachers, the indicator of their professional excellence and compliance with the standards of preschool education. Components of the above-mentioned competence formation are as follows: cognitive, motivational and operational ones with corresponding indicators. In general, the cognitive component is characterised by knowledge about peculiarities of using computer technology; the motivational component involves interest and need to use computer technology; the operational component is characterised by the level of formation of preschool teachers' professional abilities and skills providing the implementation of computer technology in the educational process of a preschool institution.

Diagnostics of the peculiarities of the formation of future preschool teachers' competence required for using computer technology in the educational process of a preschool institution was carried out at the Faculty of Preschool Pedagogy and Psychology of the South Ukrainian National Pedagogical University named after K. D. Ushynsky during 2014-2016 years. The diagnostics involved 38 third- and fourth-year students majoring in "Preschool Education". It was carried out before and after studying the disciplines "New Information Technology in Preschool Education" and "Computer Technology in Work with Children".

The level of cognitive component formation was assessed by means of the adapted test developed by V. Molodtsev [2]. The assignment embraced the following topics: "Main ICT devices", "ICT software", "Technology for graphic data processing" along with the questions to
"Computer Science" course learned before. The test consisted of 15 closed-ended questions with suggested answers (the students were supposed to choose the correct variant) and guidelines on passing the test.

In order to check the students' knowledge of necessary forms and methods of applying CT in the educational process of a preschool institution, their works were analysed, namely a set of tasks developed at two levels of complexity: the first level - reproductive - involved reproduction of the acquired information and giving one's own interpretation of it. For instance, "Prove the reasonability of using computer games in work with preschool children". The second level - research and creative presupposed the development of a plan for one's own project on a certain topic. For example, "Create a plan for the presentation "Storehouse of Morality" for children of senior preschool age".

The level of motivational component formation was assessed with the help of "The Map of Motivational Choices". The students were offered to evaluate the statements given below concerning the motives for using $\mathrm{CT}$ in the educational process of a preschool institution on a scale from one to ten according to the significance of each motive for them:

1) understanding the utility of CT in work with preschool children;

2) making the performance of preschool teacher's duties easier;

3) no need to use CT in the educational process of a preschool institution;

4) interest in applying CT;

5) aiming at self-affirmation, competitiveness;

6) forced by the circumstances;

7) receiving a grade for practical training;

8) willing to present learning material to children in an interesting and attractive manner;

9) making preparation for lessons and games with children easier;

10) gaining experience in applying $\mathrm{CT}$ in the educational process of a preschool institution.

The motives No. 1, 8, 9 demonstrate the intent to use CT in work with children. The motives No. 2, 4, 10 show the students' readiness to use CT. The motives No. 3, 5, 6, 7 are indicative of other secondary interests.

For the assessment of operational component, the students were offered to develop and present a project using CT. The project consisted of the following tasks: to develop and document the supporting notes for learning and cognitive lesson for preschool children (the suggested topics were as follows: "What do plants need for living?", "A forest is the home, protector and doctor", "Where does water come from?", "In the world of fairy tales", etc.); to select games, entertainments, experiments, fairy tales, puzzles, poems, crosswords, superstitious beliefs, proverbs, sayings for preschool children and their parents.

Also, the students were offered to do practical tasks on computers: to switch them on; to create their own folders on the desktop with the names typed with Latin 
characters; to start Microsoft Office PowerPoint, create three slides, give name to the presentation, choose design, insert a picture, attach a hyperlink, configure animation, start the slide show, save the presentation in the student's own folder; to start Microsoft Office Publisher, choose publication type "newsletter" or "fast publication", select the template, give the name to it, insert a picture, type the text using the following formatting: font type - Times New Roman, font size -12 , line space -1 , start page view, save the publication in the student's own folder; to create a video sequence in Windows Movie Maker on the topic "What is the most important job?", insert corresponding pictures (or videos), type a text, configure music; to develop Scratch-project on the topic "Let's visit Moydodyr (Washstand The Great)", save it in the student's folder.

The data obtained after the diagnostics demonstrated that $21.05 \%$ of the students had sufficiently formed competence required for using computer technology in the educational process of a preschool institution, the medium level was demonstrated by $31.58 \%$ of the students while most of them (47.37\%) had the low one.

While learning the disciplines "New Information Technology in Preschool Education" and "Computer Technology in Work with Children", future preschool teachers are trained for using CT in their future work. According to the requirements of the national standard for educational and professional training, having learned the above-mentioned courses, the students must:

- be familiar with the concepts "information technology", "information and communications technology", "computer technology in preschool education"; forms, methods and techniques of organising work with preschoolers with the help of computer technology; types of computer games for the children of senior preschool age, their characteristics and principles of their use in the classroom; criteria for assessing the efficiency of the developed computer-aided games and training programmes for children; medical, sanitary and psychopedagogical requirements for safe use of computer equipment in work with preschool children; ways of using information technology for optimisation of a preschool teacher's work (teaching process organisation and planning, preparing children for school, working with parents, career enhancement, using the Internet).

- be able to: use latest information technology when organising playing and learning activity of children as well as educational events for them at a preschool institution; apply learning and cognitive programmes and games in the educational process of a preschool institu-

\section{REFERENCES}

1.Bohush, A. M., \& Bielienka H. V. (2012). Bazovyi komponent doshkilnoi osvity $v$ Ukraini [Basic component of preschool education in Ukraine]. Kyiv: Vydavnytstvo [in Ukrainian].

2.Molodtsov, V. A., \& Ryzhikova, N. B. (2008). Informatika: testy, zadanyia, luchshie metodiki [Computer tion; analyse developed computer games and educational programmes for preschool children; use computer software (Microsoft Office: Microsoft Word, Microsoft PowerPoint, Microsoft Publisher; Paint, Paint Net; Windows Movie Maker, Windows Media Player, KMPlayer, Media Player Classic; Opera, Internet Explorer) in work with children; use IT for solving pedagogical and methodological problems in preschool teacher's work.

As part of studying the above-mentioned disciplines, the students were supposed to do individual research tasks: to analyse computer-aided educational games and programmes for preschool children; to develop classes on PC literacy, presentations for children (Microsoft PowerPoint), computer games for senior preschool children (Scratch programme), workbook for children, newsletter for parents (Microsoft Publisher), child video (Windows Movie Maker). The formation of students' competence was facilitated by organising group discussions, round table discussions, business and role-playing games at practical lessons. During practical training at preschool educational institutions the students improved their computer skills due to using computers for preparing preschool teacher's records and instructional materials for children, in work with parents and sharing experience with other specialists.

Having learned the disciplines "New Information Technology in Preschool Education" and "Computer Technology in Work with Children", only $23.7 \%$ of the students demonstrated the low level of CT competence formation, $34.2 \%$ had the medium level and the sufficient level was demonstrated by $42.1 \%$ of future preschool teachers.

\section{Conclusions}

It can be concluded that the formation of students' competence required for using computer technology in the educational process of a preschool educational institution is an integrated process, which involves psychopedagogical, methodological, technical training and the testing of the acquired knowledge and abilities in the process of practical training at a preschool educational institution. The level of the above-mentioned competence formation was assessed before and after studying the courses "New Information Technology in Preschool Education" and "Computer Technology in Work with Children" by future preschool teachers. The results of the study have shown that the level of future preschool teachers' competence formation has increased significantly after studying these disciplines.

science: tests, tasks, best techniques]. Rostov-on-Don: Feniks [in Russian].

3. Oliinyk, Yu. I. (2009). Sposoby vykorystannia informatsiinykh kompiuternykh tekhnolohii u pidhotovtsi fakhivtsiv haluzi doshkilnoi osvity [Ways of implementing information and computer technologies in training 
specialists of preschool education]. Pedahohichni nauky: zb. nauk. prats - Pedagogical sciences: Collection of

\section{ЛІТЕРАТУРА}

1. Базовий компонент дошкільної освіти в Україні / науковий керівник: А. М. Богуш, дійсний член НАПН України, проф, д. пед. наук; авт. кол-в: Богуш А. М., Бєлєнька Г. В. та ін. - К. : Видавництво, 2012. -26 c.

2. Молодцов В. А. Информатика : тесты, задания, лучшие методики / В. А. Молодцов, scientific papers, 51, 403-408. Kherson: Vydavnytstvo KhDU [in Ukrainian].

Н. Б. Рыжикова. - Ростов на Дону : Феникс, 2008. $217 \mathrm{c}$.

3. Олійник Ю. І. Способи використання інформаційних комп'ютерних технологій у підготовці фахівців галузі дошкільної освіти / Ю. І. Олійник // Педагогічні науки : зб. наук. праць. - Херсон: Видавництво ХДУ, 2009. - Вип. 51. - С. 403-408.

Ігор Іванович Раку, доктор психологічних наук, професор кафедри психології, проректор з наукової роботи і міжнародних відносин, Кишинівський державний педагогічний університет ім. I. Крянге, ул. І. Крянге 1, м. Кишинів, Республіка Молдова, Олексій Анатолійович Листопад, доктор педагогічних наук, дочент, Ірина Костянтинівна Мардарова, кандидат педагогічних наук, стариий викладач,кафедра дошкільної педагогіки, Південноукраїнський національний педагогічний університет імені К. Д. Уиинського, вул. Старопортофранківська, 26, м. Одеса, Украӥна

\section{ФОРМУВАННЯ КОМПЕТЕНТНОСТІ МАЙБУТНІХ ВИХОВАТЕЛІВ ДО ВИКОРИСТАННЯ КОМП'ЮТЕРНИХ ТЕХНОЛОГІЙ}

Розкрито особливості формування в майбутніх вихователів компетентності, необхідної для використання комп’ютерних технологій в освітньому процесі дошкільного навчального закладу на заняттях із навчальних дисциплін «Нові інформаційні технології в дошкільній освіті» і «Комп’ютерні технології в роботі 3 дітьми». Доведено, що в умовах широкого використання засобів комп'ютерної техніки в освітньому процесі дошкільного навчального закладу значно зростають вимоги до професійної підготовки вихователя, рівня його професійної компетентності. Розглянуто поняття «компетентність майбутніх вихователів до використання комп'ютерних технологій в освітньому процесі ДНЗ», виокремлено компоненти сформованості означеної компетентності майбутніх вихователів - когнітивний, мотиваційний, операційний. Когнітивний компонент характеризується наявністю уявлень щодо особливостей використання комп'ютерних технологій, мотиваційний компонент означеної компетентності передбачає наявність інтересу і потреби щодо використання комп'ютерних технологій, операційний компонент характеризується сформованістю у вихователів професійних умінь і навичок, що забезпечують упровадження комп'ютерних технологій в освітній процес дошкільного навчального закладу. Запропоновано діагностувальний інструментарій та представлено результати діагностування особливостей формування в майбутніх вихователів компетентності до використання комп'ютерних технологій в освітньому процесі ДНЗ. Вивчення сформованості когнітивного компонента відбувалося завдяки адаптованому тестовому завданню, запропонованому В. Молодцевим та аналізу продуктів діяльності студентів. Вивчення сформованості мотиваційного компонента відбувалося завдяки використанню «Карти мотиваційних виборів». 3 метою визначення операційного компоненту, студентам було запропоновано розробити і захистити навчальний проект та виконати практичні завдання - створити презентацію, публікацію, скретч-проект, відеоряд із використанням комп’ютерних програм (Microsoft Office PowerPoint, Microsoft Office Publisher, Windows Movie Maker, Scratch). У статті доведено, що формування компетентності у майбутніх вихователів до використання комп'ютерних технологій - це комплексна проблема, яка повинна включати психолого-педагогічну, методичну, технічну підготовку та апробацію знань та вмінь у процесі проходження педагогічної практики в умовах ДНЗ. Після проведення занять 3 навчальних дисциплін «Нові інформаційні технології в дошкільній освіті» і «Комп’ютерні технології в роботі з дітьми» низький рівень сформованості компетентності було зафіксовано лише в 23,7\% студентів, середній рівень у 34,2\% студентів, а достатній рівень аж у 42,1\% майбутніх вихователів дошкільних навчальних закладів.

Ключові слова: компетентність, майбутні вихователі, комп’ютерні технології, освітній процес дошкільного навчального закладу.

Подано до редакичії 10.04.2017 